\title{
Biological potential and microencapsulation of Cinnamomum cassia essential oil as an alternative for pest control in stored maize
}

\author{
Potencial biológico e microencapsullação do óleo essencial de Cinnamomum cassia como alternativa \\ para o controle de pragas em milho armazenado \\ Potencial biológico y microencapsulación del aceite esencial de Cinnamomum cassia como \\ alternativa para el control de plagas en maíz almacenado
}

Received: 10/26/2021 | Reviewed: 11/05/2021 | Accept: 11/08/2021| Published: 11/13/2021

\author{
Mariane Minozzo \\ ORCID: https://orcid.org/0000-0003-0886-9707 \\ Universidade Regional Integrada do Alto Uruguai e das Missões, Brazil \\ E-mail: mariane_min@hotmail.com \\ Juliana Steffens \\ ORCID: https://orcid.org/0000-0001-6607-2283 \\ Universidade Regional Integrada do Alto Uruguai e das Missões, Brazil \\ E-mail: julisteffens@uricer.edu.br \\ Geciane Toniazzo Backes \\ ORCID: https://orcid.org/0000-0001-8652-8399 \\ Universidade Regional Integrada do Alto Uruguai e das Missões, Brazil \\ E-mail: gtoniazzo@uricer.edu.br \\ Natalia Paroul \\ ORCID: https://orcid.org/0000-0001-9809-7944 \\ Universidade Regional Integrada do Alto Uruguai e das Missões, Brazil \\ E-mail: nparoul@uricer.edu.br \\ Rogério Luis Cansian \\ ORCID: https://orcid.org/0000-0002-1857-9036 \\ Universidade Regional Integrada do Alto Uruguai e das Missões, Brazil \\ E-mail: cansian@uricer.edu.br
}

\begin{abstract}
This study proposes a review of biological potential of cinnamon (Cinnamomum cassia) essential oil with a focus on microencapsulation as an alternative to control the occurrence of pests in stored maize grains. Due to the demands on corn productivity, there is the need to improve grain storage processes and conditions, since that in this stage there are quantitative and/or qualitative losses, mainly due to the maize weevils (Sitophilus zeamais) and the incidence of mycotoxin-producing fungi (Penicillium crustosum, Alternaria alternata and Aspergillus flavus). The control of these pests is usually carried out with chemical insecticides, which can leave toxic residues in the grain. Therefore, the microencapsulation of essential oils appears as a promising alternative, considering the volatility of aromatic compounds, which are largely responsible for the activity against pests.
\end{abstract}

Keywords: Cinnamomum cassia; Trans-cinnamaldehyde; Essential oil; Encapsulation; Bioinsecticide; Biofungic.

\section{Resumo}

Este estudo propõe uma revisão do potencial biológico do óleo essencial de canela (Cinnamomum cassia) com foco na microencapsulação como alternativa para o controle da ocorrência de pragas em grãos de milho armazenados. Devido às demandas na produtividade do milho há a necessidade de melhorar os processos e condições de armazenamento dos grãos, visto que nesta fase há perdas quantitativas e/ou qualitativas, principalmente devido ao gorgulho do milho (Sitophilus zeamais) e à incidência de micotoxinas produtoras. fungos (Penicillium crustosum, Alternaria alternata e Aspergillus flavus). O controle dessas pragas costuma ser feito com inseticidas químicos, que podem deixar resíduos tóxicos no grão. Portanto, a microencapsulação de óleos essenciais surge como uma alternativa promissora, considerando a volatilidade dos compostos aromáticos, os quais são os grandes responsáveis pela atividade contra pragas.

Palavras-chave: Cinnamomum cassia; Trans-cinamaldeído; Óleo essencial; Encapsulamento; Bioinseticida; Biofúngico. 


\section{Resumen}

Este estudio propone una revisión del potencial biológico del aceite esencial de canela (Cinnamomum cassia) con un enfoque en la microencapsulación como alternativa para controlar la ocurrencia de plagas en granos de maíz almacenados. Debido a las demandas sobre la productividad del maíz existe la necesidad de mejorar los procesos y condiciones de almacenamiento del grano, ya que en esta etapa existen pérdidas cuantitativas y/o cualitativas, principalmente por el gorgojo del maíz (Sitophilus zeamais) y la incidencia de micotoxinas productoras. hongos (Penicillium crustosum, Alternaria alternata y Aspergillus flavus). El control de estas plagas se suele realizar con insecticidas químicos, que pueden dejar residuos tóxicos en el grano. Por tanto, la microencapsulación de aceites esenciales aparece como una alternativa prometedora, considerando la volatilidad de los compuestos aromáticos, que son en gran parte responsables de la actividad contra las plagas.

Palabras clave: Cinnamomum cassia; Trans-cinamaldehído; Aceite esencial; Encapsulación; Bioinsecticida; Biofungicida.

\section{Introduction}

The increase in maize (Zea mays L.) productivity is intrinsically linked to the improvement of the harvesting process and grain storage conditions. However, prolonged storage can only be carried out when the practices of harvesting, cleaning, drying, insect control and fungi prevention are correctly adopted. In general, the main causes of loss of quality in stored agricultural products are pest insects, such as the weevil (Sitophilus zeamais Mots. (Coleoptera: Curculionidae)) and the grain moth (Sitotroga cerealella Olivier (Lepidoptera): Gelechiidae) (Lorini et al., 2015). Maize grains are also susceptible to fungal contamination, especially Alternaria, Aspergillus and Penicillium. The proliferation of these fungi in maize not only leads to a reduction in yield, quality and economic losses, but also produces carcinogenic secondary metabolites, called mycotoxins, which pose a threat to human and animal health (Sun et al., 2017; Ti et al., 2019; Tournas \& Niazi, 2017).

The excessive use of chemical insecticides, considered as highly effective long-term management tools, has made many insect species physiologically or behaviorally resistant (Boyer et al., 2012). Added to this, the negative consequences on the environment and society have driven the use of natural plant products, such as essential oils (EOs) with insecticidal activity, in pest control during grain storage (Regnault-Roger et al., 2012).

Most aromatic plants rich in EOs have potential to act as insecticides or repellents, thus being able to play an important role in protecting grains against pest damage (Suthisut et al., 2011). OEs are referred to as reduced risk pesticides. In addition to being well received by consumers for domestic use and against pests, these green pesticides are also effective for the production of organic food.

The active principles of spices, such as cinnamon (Cinnamomum sp.), are located in the essential oil fraction (EO) (Pereira \& Maia, 2007). Cinnamomum cassia (C. cassia) EO has insecticidal, repellent and antifungal properties (Kim et al., 2003; Sun et al., 2016; Tripathi et al., 2009; Wang et al., 2019). Applications of OEs are limited due to the volatility of the compounds. However, the microencapsulation process provides protection and stability to these volatiles, with the possibility of controlled release of EO for action as a biological pesticide (Rodríguez et al., 2016; Souza et al., 2019). Encapsulation also increases the solubility of EOs, decreasing the need to use surfactants. In the microencapsulation of EOs, it is interesting to use techniques and combination of wall materials capable of reducing the loss of volatiles (Osorio-Tobón et al., 2016).

This review intends to address the relevant data that justify the microencapsulation of $C$. cassia essential oil as an antifungal, insecticide and repellent alternative to conventional pesticides for the control of maize weevil (Sitophilus zeamais) and fungi (Penicillium crustosum, Alternaria alternata and Aspergillus flavus) in stored grains.

\section{Methodology}

This work consists of a systematic literature review, developed by bibliographic research carried out on scientific articles, dissertations and theses from online databases and research portals: Wiley Online Library, Science Direct, Scielo 
(Scientific Eletronic Library Online), Elsevier, Pubmed and Google Scholar. Complete works published between 2010 and 2021 were used, without disregarding relevant works from previous years. The main search terms were Microencapsulation, essential oil, Zea mays, stored grains, bioinsecticide, reppelent, fungic, Sitophilus zeamais, Penicillium crustosum, Alternaria alternata, Aspergillus flavus, Cinnamomum cassia, trans-cinnamaldehyde, excluding articles that did not have several simultaneous terms and that did not focus on the research objective (review of the biological potential of Cinnamomum cassia essential oil with a focus on microencapsulation as an alternative to control the occurrence of pests in stored maize grains).

\section{Results and Discussion}

\subsection{Maize culture and its storage}

Maize (Zea mays L.) is a member of the grass family (Doebley, 1990). The economic importance of maize it is related to several forms of its use, since animal feed to high-tech industry. As a human food base, it is very versatile and can be consumed directly or indirectly. Its cultivation is not essentially restricted to food industry, where small properties, even without technological resources, use this culture as a means of survival, being evident the economic and social impact (Duarte et al., 2010).

Brazil stands out in world grain production, being considered the third largest maize producer in the world. The maize production chain is one of the most important economic segments of Brazilian agribusiness, where the primary maize production corresponding to approximately $37 \%$ of the total grain produced in the country, from 35,715.6 t, in 1997 harvest, to $100,566.1 \mathrm{t}$, in 2019 harvest, with an increase of $181.6 \%$ (Conab, 2021).

Maize production occupies about 12 million hectares throughout the national territory. Appropriate potential is identified for the use of high technology for production above $16 \mathrm{t} / \mathrm{ha}$, but the use of low investment technology still predominates, which has maintained the national average productivity around $5.1 \mathrm{t} / \mathrm{ha}$, according to IBGE data from 2021 .

The Brazilian maize production is directed to two destinations, the consumption in the rural establishment and by consumer market, where the commercialization flows are alternated between feed factories, chemical industries, in natura product and export (Maciel \& Tunes, 2021).

Grain yield can be affected by several factors, among which, the action of pest insects is mentioned as one of the main ones, as it prevents the better use of the productive potential of hybrids and cultivars, due to attacking from sowing to harvest, causing damage to roots, stalks, leaves and ears (Hernandez Nopsa et al., 2015).

The possibility of storage for long periods of time, without significant loss of quality, gives a positive characteristic to maize, since production occurs in harvests (Santos, 2006). However, planning for prolonged storage, aiming to ensure quality, must start long before the grains reach the storage units and take into account the losses that can occur from the beginning, with the inadequate choice of varieties, fertilization, irrigation, mode of harvest, transport, processing within the unit and various poststorage factors, such as moisture content and the temperature of the grain mass, presence of impurities, contamination of storage structures, variations in temperature and relative humidity of the air, which influence the main processes what grains are subject to during storage: respiration and proliferation of insects, pests and microorganisms, especially fungi (Goneli, 2021), including toxigenic species such as Aspergillus flavus (A. flavus) (Chu et al., 2013).

Maize (Zea mays L.) is a plant characterized by two vegetative cycles, the short cultivar cycle, present pollination 30 days after emergence, and the normal cycle with a maximum of 300 days. In Brazil, its cycle can vary from 110 to 160 days, due to the characterization of the cultivars, period between sowing and harvesting (Fancelli, 2015). Thus, the maize storage due to the off-season periods, is of fundamental importance for the conservation of its quality, having the function of keeping it healthy, clean and free from pesticide residues usually used to combat pests that attack the grains stored (Santos, 2006). 
Once stored, grains are subject to transformation, deterioration and loss due to interactions between physical, chemical and biological phenomena, which implies that factors such as temperature, humidity, oxygen availability, microorganisms, insects, rodents and birds are constantly monitored (Lorini et al., 2015), thus minimizing post-harvest losses of the most different kinds of commodities, and still keeping the metabolism (respiration) of grains at reduced levels, thus applying integrated management, reducing the need for excessive use of chemical substances for control (Goneli, 2021).

In Brazil, maize production losses are evidenced as a result of logistics, poor distribution and location of warehouses and also the deficiency in storage combined with the precarious conditions of many structures (Fassio et al., 2018). Thus, research in the harvesting and storage segment is essential for grain conservation and loss reduction.

Carelessness or failures in the storage process can cause production losses due to the action of insect pests, fungi and their mycotoxins, in addition to pesticide residues. Grains contaminated with mycotoxins, secondary metabolites of some species of fungi such as Aspergillus spp. (aflatoxins and ochratoxins), Fusarium verticillioides, Fusarium subglutinans (fumonisins), Fusarium graminearum (trichothecenes zearalenone), Fusarium sporotrichioides (T-2 toxin), Penicillium spp. (ochratoxins) and Alternaria alternata (A. alternata), cause a great concern for human and animal health due to their high toxicity (Sun et al., 2017; Ti et al., 2019; Tournas \& Niazi, 2017). These mycotoxins have an accumulative character in the body, even in low concentrations they are capable of causing pulmonary edema, apathy, hemorrhages, anorexia, brain and liver necrosis and chronic diseases such as cancer, liver cirrhosis, immunosuppression, mutagenicity and nephropathies (Ti et al., 2019; Bennett \& Klich, 2003).

Damage caused by insects is another factor that increases the risk of fungal infections in grains, in addition to causing losses due to weight reduction, which depreciates the commercial value, reduces nutritional value and favors the deterioration of product. In general, the main causes of loss of quality in stored agricultural products are pest insects, such as the weevil (Sitophilus zeamais Mots. (Coleoptera: Curculionidae)) and the grain moth (Sitotroga cerealella Olivier (Lepidoptera): Gelechiidae)). The grains can be infested in the crop, with the insects already in the grains migrating to the warehouses after harvesting, or they can already be present in the warehouses. According to data from FAO and of Ministério da Agricultura, Pecuária e Abastecimento (MAPA) of 2015, the average quantitative losses of grain per year are around $10 \%$ of the total produced (Lorini et al., 2015; Mapa, 2020).

\subsection{Maize crop losses during storage period}

Millions of tons of cereal grains are lost globally each year during storage. These losses are largely due to contaminants including fungi, mycotoxins and insect pests which compromise grain quality. The investment in the acquisition of knowledge aiming at an adequate management, allows a significant reduction in losses (Mesterházy et al., 2020).

It is extremely important to know the classes of insect pests, as well as the damage caused by them during storage, to establish the best management strategy, avoiding major losses in grain quality (Stejskal et al., 2015). For a better definition of the management to be used in grains or seeds, it is necessary to know the eating habits of each insect pest. According to Lorini et al. (2015), pests can be classified as primary or secondary.

Primary pests - can be called internal or external pests depending on the part of the grain they attack, and the target is whole and healthy grains and seeds. Internal pests pierce the grains, consume their internal content and remain in this region during their cycle, in addition to allowing the installation of other deterioration agents, such as the S. zeamais bug. On the other hand, external pests aiming only feeding, they destroy the outside of the grain or seed (husk) to feed the inside part, but without developing inside. As an example, moths.

Secondary pests - these pests do not attack healthy and whole grains, they need that the grains are cracked, broken or damaged by primary pests. The multiplication of these pests is very fast, which causes enormous damage. 
Bugs and moths are two important groups of pests that attack stored grains and seeds and have a high reproductive capacity, which makes it possible to reach the grain masses throughout the storage place. Bugs, also known as weevils, pierce the grains reaching their interior, while moths (Lepidoptera) remain on the surface, causing less damage than the first ones (Coleoptera) (Gallo et al., 2002).

Among the bugs species, $S$. oryzae and $S$. zeamais stand out for the damage they cause, which justifies most of the chemical control (Lorini et al., 2015). Females of S. zeamais oviposition inside the grains and the larvae (offspring), due to feeding on the inner parts of grain, reduce its weight and, consequently, the nutritional and economic values, and also reducing the viability of the seed. and cause contamination by excreta and debris from their bodies (Suleiman et al., 2015). Sitophilus Zeamais (Motschulsky, 1885) and Sitophilus Oryzae (Linné, 1763) belong to the order Coleoptera and the Curculionidae family, they can occur together in the same mass of grains or seeds, being very similar in morphological terms, whose differentiation is performed only through the study of genitalia (Lorini et al., 2015).

Bugs reach $3 \mathrm{~mm}$ length as adults, with dark brown coloration, lighter spots on the elytra (forewings), visible soon after emergence. They have a proboscis-shaped cephalic extension, known as a curved rostrum. The larvae are light yellow in colour, with a dark brown head and white pupae. The oviposition period is 104 days, with 282 being the average number of eggs per female. The longevity of females is 140 days. The incubation period ranges from 3 to 6 days and the egg cycle to adult emergence is 34 days (Suleiman et al., 2015).

Preventive measures, such as the elimination of waste from the entire facility (corridors, walkways, tunnels, elevators and hoppers), in the warehouse, are the simplest and least costly to control the infestation of the insect pest, where are the most important for grain preservation (Lorini et al., 2015).

Among the mycotoxin producers, the genus A. alternata, A. flavus and Penicillium crustosum (Prestes et al., 2019; Shen et al., 2020; Ti et al., 2019) stand out, which has a development provided by unfavorable storage conditions, such as high temperature and humidity, influencing the quality of the grains (Mannaa \& Kim, 2017).

These mycotoxins are secondary metabolites, of low molecular mass ( $700 \mathrm{u})$, which compromise the immune response in humans and animals and, consequently, reduce resistance to infectious diseases, causing cancer, mutagenic, teratogenic and immunosuppressive diseases ( $\mathrm{Ti}$ et al., 2019). Studies evaluated the incidence of liver cancer due to ingestion of aflatoxincontaminated food produced by A. flavus from contaminated corn commodities (Rodrigues et al., 2011; Wu, 2015).

Mycotoxins can be ingested through foods of animal or vegetable origin that contain them as waste [35]. Several preventive and strategic measures should be used to minimize the occurrence of mycotoxins in raw materials and processed foods, both in pre-harvest, as well as good agricultural practices, as well as adequate storage conditions in post-harvest, considering the fact of contamination of the fungal stored grains are a constant concern in the food industry (Patriarca \& Pinto, 2017; Rocha et al., 2020).

The elimination of residues from grain and dust is also recommended as a way to avoid the proliferation of insects and fungi, which can again infest the storage units, being advised to burn or bury this material. Then, the cleaning of the place is carried out, usually by means of thermal fogging and/or spraying with insecticides to eliminate insects present on walls, machinery and equipment. Thus, the storage unit, after complete sanitation, will be able to receive clean and dry grains, with 12 and $13 \%$ of the adequate moisture content to help prevent infestation (Lorini et al., 2015). The use of chemical insecticides is one of the most used methods to control pests of stored grains and seeds, however, it has been showing restrictions of use as pest resistance insecticides arises (Isman, 2006). 


\subsection{Synthetic insecticides}

Synthetic insecticides have been widely used since the 1940s in storage units to combat and control grain pests, due to their ease of handling, low cost and effectiveness (Casida \& Durkin, 2013). Despite the harmful effects of insecticides, this tactic remains dominant in pest management against insects from stored products, particularly in warmer climates, due to its larvicidal and adulticidal power (Vélez et al., 2017).

The use and recommendation of pesticides are largely based on acute lethality studies, which, although valuable, neglect the likely occurrence and importance of potential sublethal effects on the pest species and associated community. Due to the breakdown of insecticide molecules over time, irregular distribution of insecticides and/or insect resistance to treated surfaces, target species are subject to sublethal doses for much longer than lethal doses, which can induce insects to withdraw from areas contaminated with insecticides, increasing survival (Vélez et al., 2019).

The increased use of insecticides has caused their accumulation in the biotic and abiotic segments of ecosystems, and even if some pesticides do not exceed the permitted limits, the consequences of their accumulation over time in the organism are not known. The official residue control of each agricultural product is based on the tolerance (maximum residue limit MRL) and the withdrawal period (Jardim et al., 2009).

Spraying with residual insecticides (pyrethroids and organophosphates) is the main preventive control method against warehouse pests. Nowadays, the most used organophosphates are methyl pirimiphos and fenitrothione with MRL for maize of $5.0 \mathrm{mg} . \mathrm{Kg}^{-1}$ and $1.0 \mathrm{mg} . \mathrm{Kg}^{-1}$, respectively, and those of the pyrethroid group, bifenthrin, permethrin and deltamethrin, whose MRLs for maize are $0.02 \mathrm{mg} . \mathrm{Kg}^{-1}, 0.1 \mathrm{mg} . \mathrm{Kg}^{-1}$ and $1.0 \mathrm{mg} . \mathrm{Kg}^{-1}$, respectively (Faroni et al., 2014).

Due to the resistance of maize weevil to pyrethroids, in the early 2000s, an alternation between these and organophosphate compounds began to take place, which reduced the self-defense of pests (Santos et al., 2009). There are reports of the occurrence of residues not only in stored grains, but also in their by-products, with an increase or decrease in concentration in relation to whole grains. In general, there is a reduction in industrialized products, but in some cases, the opposite can also occur. Therefore, changes in residue levels during grain processing must be taken into account to establish the MRL levels and the grace period for each by-product (Trevisan \& Baptista, 2000).

In Brazilian legislation, the maximum residue limits (MRL) of some insecticides are higher than the dosage recommended by the manufacturers, allowing a priori the consumption of the grain soon after treatment (Trevisan \& Baptista, 2000). As a result, there is the induction of resistance in insect pests, which depends on the volume and frequency of insecticide applications used in management. The inherent abilities of insect species is also an important factor in the development of resistance. Among the evolutionary phenomena, resistance to insecticides has the greatest economic impact, however, it only received attention after it was reported in insect vectors of human diseases, such as the housefly (Musca domestica), in 1946 (Naqqash et al., 2016).

Among the main factors influencing the development of resistance to insecticides are the length of the pest's life cycle, reproductive potential and environmental stress (Naqqash et al., 2016). Resistance in all classes of insecticides is an impediment to the management of nearly all important invertebrate pests in agriculture and public health (Benelli, 2015).

The search for and encouragement of the use of less harmful bioactive compounds and the sustainable use of pesticides is evident in many countries of the European Union, which can be demonstrated by the creation of European Regulation N. 1107/2009/EC and Directive 2009/128 /EC of the European Parliament. However, the fact that they are biopesticides does not make these compounds non-toxic, so safety information must be considered and the use of biopesticides must follow the recommendations as indicated by the manufacturer (Villaverde et al., 2014).

As fungal control, several strategies are used in post-harvest, such as physicochemical treatments, chemical fungicides and sulfur dioxide fumigation, combined with processing and storage technologies under controlled conditions. However, each 
method has its limitations, in addition to being associated with resistance to fungi and new secondary pests, due to carelessness and overuse, also contributing to the increase in the levels of toxic residues of synthetic fungicides in food and in the environment (Sonker et al., 2014).

Thus, the search for sustainability in agriculture includes research and development in the implementation of new molecules of lower risk, replacing the older insecticide/fungicide molecules, often referred to as biopesticides (Isman \& Grienesen, 2014; Villaverde et al., 2014). Among these are botanicals, both crude extracts and natural plant-derived chemicals (Isman \& Grienesen, 2014). Plants have developed complex and often effective chemical arsenals to limit damage from herbivorous insects (Mithöfer \& Boland, 2012) and the use of botanicals is one of many strategies to protect plants from microbial pathogens (Yoon et al., 2013) and nematodes (Andrés et al., 2012). Many plants defensive metabolites have clearly demonstrated insecticidal (Rattan, 2010) or repellent mechanisms (Maia \& Moore, 2021).

\subsection{Biological properties of essential oils}

Chemical insecticides have been regarded as highly effective tools, but their overuse has made many insect species physiologically or behaviorally resistant (Boyer et al., 2012). Added to this, the negative consequences on the environment and society have driven the use of natural plant products, such as essential oils with insecticidal activity, to control pests during storage (Regnault-Roger et al., 2012).

Essential oils are rich in bioactive compounds, which give them biological activity and, when incorporated into polymers, can prolong bioavailability through controlled release (Rodríguez et al., 2016). Most aromatic plants rich in EOs have the potential to act as insecticides, repellents or food deterrents, thus playing an important role in protecting grains against pest damage (Suthisut et al., 2011). In addition to having a natural bioactive capacity against numerous groups of pests, resulting, in large part, from the evolutionary development aimed at their own defense and in response to possible attacks (Gonçales et al., 2016).

Several researches in the field of pest management reveal that certain essential oils from plants and/or their constituents have a broad spectrum of activity against insect pests and pathogenic fungi (Isman, 2000). EOs have specific chemical structures, produced as secondary metabolites in plants, are complex mixtures of low molecular weight such as terpenes and aromatic compounds (Torre et al., 2015; Tripathi et al., 2009), these substances develop functions related to volatility, playing ecological functions in pest management of stored products (Knaak \& Fiuza, 2010).

These constituents commonly found in seeds, stems, leaves and flowers can be obtained by various methods, such as hydrodistillation, hydrocarbon extraction, chlorinated solvent extraction, enzymatic treatment and fermentation, supercritical $\mathrm{CO}_{2}$ extraction and steam distillation, where the latter being the most used in commercial distillation of EOs. The distinction in the organoleptic profile indicates a difference in composition of oils obtained by solvent extraction compared to distillation, which can also influence the biological properties. These compounds have multiple mechanisms of action, and may even reduce the development of resistance in pest insects (Pavela \& Benelli, 2016).

Among the functions of these compounds used to control pest insects, the insecticide, a sterilizing action, or that only drive insects away from plants, such as repellents and food inhibitors, stand out (Saito et al., 2004). The repellent activity is the most common of EOs and its major components, whose action occurs through interaction with the insect's integument through contact, causing even asphyxia, also can to acting on digestive and neurological enzymes. EOs are volatile and therefore need to be stored in airtight containers in the dark to avoid compositional changes. It is estimated that there are approximately 3,000 known EOs, of which 300 are commercially important, destined, among other segments, to the food industry (Bakkali et al., 2008). 
The chemical composition of EO is the key factor for biological activities, being often attributed to its main compounds (Burt, 2004), while minor compounds can exert a synergistic effect (Ojeda-sana et al., 2013), contributing to increase the biological action of oils and enabling the application as an alternative to synthetic insecticides (Pavela \& Benelli, 2016; Pavela, 2016).

The insecticidal effect of EOs is not fully elucidated, but the symptoms of intoxicated insects suggest a neurotoxic effect (Tripathi et al., 2009). Different sites of action of OEs in the nervous system of insects are described: inhibition of acetylcholinesterase, positive modulation of GABA (gamma-aminobutyric acid) receptors, and activation of octopamine receptors (Jankowska et al., 2017), and Koul et al. (2008) reported that these compounds are relatively non-toxic to mammals. There are many advantages of using EOs as pesticides, among which are: i) obtaining renewable resources, ii) degradable, iii) developing a slow resistance process, iv) no residues in food, v) easy obtainment and access (Roel, 2001).

Due to the numerous types of effects of EOs in pest control of stored products, most studies regarding the control of these pests with EOs have been focused on stored grain pest insects, such as S. zeamais (Papachristos \& Stamopoulos, 2002; Nerio et al., 2009). Essential oils may have fumigant activity (Tripathi et al., 2009; Wang et al., 2019), contact insecticidal activity (Schmidt \& Streloke, 1994; Tripathi et al., 2009; Mossi et al., 2014; Cansian et al., 2015; Vedovatto et al., 2015; Wang et al., 2019), repellent activity (Cosimi et al., 2009; Tripathi et al., 2009; Mossi et al., 2014; Cansian et al., 2015; Wang et al., 2019), acaricides (Nwanade et al., 2021, anti-feeders (Huang et al., 1997), or affect some biological parameters such as growth rate, lifespan and reproduction (Pascual-Villalobos, 1996).

Mossi et al. (2011) evaluated the insecticidal and repellent effect of essential oils of Eucalyptus dunnii, E. saligna, E. benthamii, E. globulus and E. viminalis in the control of Sitophilus zeamais in maize grains. The essential oil of Eucalyptus sp. presented insecticidal and repellency against S. zeamais Motschulsky. The authors concluded that although from an economic point of view synthetic chemicals are still more frequently used as repellents, natural products (essential oils) have the potential to provide efficient and safer repellents for humans and the environment.

Betancur et al. (2010) investigated the insecticidal properties of EO of fresh Peumus boldus Molina leaves against adult maize weevil (S. zeamais) under laboratory conditions. The highest insect pest mortality (100\%) was achieved at a concentration of $4 \%$, by in vitro contact. When evaluating this same concentration of EO in vivo, applied to maize grains impregnated with insect pests, was obtained mortality of $98.7 \%$. The fumigant action of the EO was also tested, obtaining $100 \%$ of mortality when $35 \mu \mathrm{L}$ of oil was applied in $0.15 \mathrm{~L}$ (air volume) for $6 \mathrm{~h}$. The residual effect was significant for 5 days and did not affect corn grain germination. All treatments were repellent for adults of S. zeamais and maize grain germination was not affected.

Torres et al. (2014) evaluated, under laboratory conditions, the activity as a contact insecticide against adult and immature insects, residual and repellent effect, and effect on seed germination of the EO of Laurelia sempervirens against $S$. zeamais. The highest toxicity by contact activity was achieved using concentrations above $10 \mathrm{~mL}$ of this essential oil per $\mathrm{kg}$ of grain (100\% mortality). The dose of $175 \mu \mathrm{L}$ of essential oil per liter of air showed significant toxicity, through the fumigant activity, causing $72.5 \%$ mortality in insects. A residual effect of contact toxicity was observed for 15 days and there was no influence on germination. The study considers promising the use of $L$. sempervirens essential oil to control maize weevils, where has been observed a repellent effect in all treatments.

Cosimi et al. (2009) investigated the repellency of essential oils extracted from laurel (Laurus nobilis), bergamot (Citrus bergamia), fennel (Foeniculum vulgare) and lavandim (Lavandula hybrida) against adult S. zeamais, where bergamot and lavandim EOs were the most efficient oils.

Wang et al. (2019) evaluated the chemical composition of essential oils from four aromatic plants, Cinnamomum burmannii, Cinnamomum migao, Litsea pungens and Laurus nobilis, and their fumigant effects, contact toxicity and repellent activity on T. castaneum (Coleoptera: Tenebrionidae; red flour) and L. bostrychophila (Psocoptera: Liposcelididae; booklice), 
which cause serious damage to stored products, in addition to being resistant to some chemical insecticides. The results obtained indicate that all EOs obtained insecticidal and repellent activity against the evaluated insects.

The use of EOs in food products is on the rise as consumers are more aware of the potential health problems associated with synthetic preservatives. Therefore, there is a growing interest in the use of natural antioxidants and antimicrobials for food preservation, inhibiting the growth of foodborne pathogens and prolonging the shelf life of food products (Tajkarimi et al., 2010). Ribeiro-Santos et al. (2017), evaluated the chemical composition, with the techniques of gas chromatography and ultrahigh performance chromatography, and the in vitro antimicrobial and antioxidant activity of EOs extracted from basil (Ocimum basilicum), cinnamon of different species, (Cinnamomum zeylanicum Blume and Cinnamomum cassia) and rosemary (Rosmarinus officinalis), and these oils showed good biological activity, indicating potential to be used as additives in the formulation of active packaging.

\subsubsection{Biological properties of the essential oil of cinnamon (Cinnamomum cassia)}

Cinnamon (Cinnamomum sp.) is one of the oldest known spices and is currently one of the most commonly used as a flavoring in foods. In ancient Egypt, where it was considered more precious than gold, it was used as an embalming agent, aromatic drink and pharmaceutical. It was referred to in one of the earliest books on Chinese botanical medicine, dated around 2700 B.C. (Costa, 2002).

It is a tree of perennial cycle that reaches from 8 to $9 \mathrm{~m}$ in height, whose origin is Asian and belongs to the family of Lauraceae, being cultivated mainly in tropical and subtropical Asia, in Australia and in the Pacific Islands. Cinnamon is obtained from the trunk of the cinnamon tree, a tree that has its dry branches separated from its peel, reddish-brown, which are very fragrant (Schiper, 1999). Due to its antimicrobial (Barbosa et al., 2021), antioxidant (Attokoran, 2017) and anticancer (Duguta \& Cheryan, 2021) properties, cinnamon has been used in foods, condiments, cosmetics, and medicines (Mathew \& Abraham, 2006; Utchariyakiat et al., 2016). The genus Cinnamomum contains around 350 species, ranging from shrubs to small to medium sized trees (Rohwer, 1993).

The inner part of the peel of trunk and branches constitute the commercially used cinnamon (Lima et al., 2005). It has been shown that the active ingredients of spices are located in the essential oil fraction (Pereira \& Maia, 2007). The essential oil from the peel has E-cinnamaldehyde as its major compound (97.7\%), while cinnamon leaf the main compound is eugenol (87\%) (Singh et al., 2007).

Cinnamaldehyde is considered a GRAS (Generally Recognized as Safe) food additive by the Food and Drug Administration (FDA) (Torre et al., 2015) and is widely used in food (Friedman et al., 2000) and cosmetics (Lee \& Balick, 2005). However, due to its particular taste, volatility and lipophilic nature, the use of cinnamaldehyde in food preservation is limited in its free form (López-Mata et al., 2018). Eugenol, used primarily as a flavoring in foods, is recognized by the FDA as safe when used in foods in concentrations up to $1,500 \mu \mathrm{g} \cdot \mathrm{mL}^{-1}$ (Pereira \& Maia, 2007).

The EOs of Lauraceae species have repellency activity against Coleoptera insects (Tripathi et al., 2009). Some constituents, such as terpenes and phenylpropanoids, may have insecticidal and/or attractive properties (Voris et al., 2017), being referred to as reduced risk pesticides. In addition to being well received by consumers for domestic use and against pests, these green pesticides are also effective in the production of organic food. Markellou et al. (2009) reported the acceptance and effectiveness of some constituents of EOs, such as eugenol, by the European community as organic pesticides, although with high toxicity (Cansian et al., 2017).

Cinnamaldehyde, a pale yellow viscous liquid, is responsible for the flavor and odor of cinnamon. It was isolated from cinnamon OE by Dumas and Peligot (1834) and synthesized in laboratory by Chiozza (1856) and Attokaran (2017). It has many activities with pharmacological potential, such as antimicrobial, anti-inflammatory, angiogenic and healing, to being considered 
of low toxicity. However, there is a need of more studies on the mechanism of action of these activities in order to provide the safe use of this compound. Normally, trans-cinnamaldehyde is related to the high antimicrobial activity of cinnamon EO in addition to having antifungal and stimulant properties (Andrade-Ochoa et al., 2015; Sun et al., 2016; Xie et al., 2017).

Sun et al. (2016) evaluating the antifungal effect of cinnamaldehyde extracted from the leaves of cinnamon ( C. cassia) against $A$. flavus, observed an efficient inhibition on radial growth, spore production, mycelium formation and aflatoxin B1 biosynthesis of this cosmopolitan fungus, being dose dependent. Andrade-Ochoa et al. (2015) showed a good antifungal activity of trans-cinnamaldehyde against Rhizoctonia solani and Fusarium oxysporum, which was related to the presence of conjugated double bonds and the length of the carbon chain outside the ring, another factor that may have an influence is the lipophilicity of the compound.

The insecticidal activity of cinnamon EO (C. Cassia) on bean (Callosobruchus chinensis) and rice (Sitophilus oryzae) weevils was reported by Kim et al. (2003). The EO tested through direct contact with insects reported 100\% mortality in both rice and bean weevils.

Ribeiro-Santos et al. (2017) evaluated both the antimicrobial activity against Escherichia coli, Staphylococcus aureus and Penicillium spp., as well as the antioxidant activity of Cinnamomun cassia and Cinnamomun zeylanicum EOs. These EOs showed strong antimicrobial activity, and the EO of $C$. cassia showed greater efficiency in inhibiting the growth of the tested microorganisms and its main compound, cinnamaldehyde, showed the greatest antimicrobial effect, followed by eugenol. The EO from C. zeylanicum and its main compound, eugenol, showed the highest antioxidant activity. Clove oil has also been shown to be active in the degradation of biofilms formed by Candida tropicalis (Hamzah et al., 2022).

Regarding the mechanisms of activity of eugenol and cinnamaldehyde, more than one may be involved, however, the importance of alternative mechanisms can be discounted if there is a rapid inhibition of energy generation. This is because cells that are unable to generate energy are also unable to reproduce or alter metabolism to adapt to the antimicrobial challenge. The effects on energy generation clearly play an important role in the activity of eugenol and cinnamaldehyde at bactericidal concentrations (Gill \& Holley, 2004). Gil and Holley (2004) proposed that the possible mechanisms of inhibition of energy generation are the inhibition absorption or utilization of glucose and the effects on membrane permeability.

Although these EOs have compounds with insecticidal properties, little is known about the effectiveness of these products in controlling of insect pests of stored grain. Furthermore, due to the need to use synergistic compound, low persistence, scarcity of natural resources, need for chemical standardization and quality control, difficulty in recording and cost make it difficult to use it on a large scale in the field (Corrêa \& Salgado, 2011). These difficulties can be overcome with the inten sification of research on the subject.

\subsection{Microencapsulation of essential oils}

The microencapsulation process is a unitary operation that involves packaging of solid particles or small droplets of substance such as pigments, nutrients or enzymes into another substance. An emulsion containing the substance to be encapsulated and an encapsulating agent is used, with a subsequent drying process. The encapsulated compound is called core or filling, active agent, internal phase or payload phase and the envelope material, which forms the capsule, is called encapsulant, covering or wall (Devi et al., 2017).

Capsules can be classified in terms of size, larger than 5,000 $\mu \mathrm{m}$ are classified as macrocapsules, between 1 and 1,000 $\mu \mathrm{m}$ microcapsules and between 10 and 1,000 nm as nanocapsules (Fávaro-Trindade et al., 2008; Rodíguez et al., 2016). Depending on the wall material and the encapsulation technique, two types of encapsulated particle morphology can be obtained, microcapsules and microspheres. The first have a defined core and the others have the filling dispersed in the matrix (Costa et 
al., 2013). Nanomaterials have become promising in nanochemistry because their smaller sizes with high surface areas provide enhanced catalytic activity compared to bulk materials (Mahesh et al., 2022).

For application in food, some requirements must be met, which limiting the possibilities among the various materials available for this purpose (Eandrey et al., 2010). Initially, encapsulating or wall materials should be GRAS. Another important factor is to consider the functionality that is desired with the encapsulation, the appropriate concentrations, the release mechanism and the stability requirement (Shishir et al., 2018). Characteristics such as low viscosity, ability to disperse or emulsify the active material, no reactivity with the encapsulated substance, soluble in solvents allowed in the food industry and low cost must also be observed (Desai \& Park, 2005).

Carbohydrates (starches, dextrins, celluloses, gums and chitosan) are the class of materials most used as encapsulating agents because they have the most relevant characteristics, although in some processes a mixture involving other groups of nutrients such as proteins (gluten, casein, whey protein isolate, gelatin and albumin) and lipids (paraffin, wax, stearic acid, tristearin, monoglyceride, oils, hydrogenated fat and diglycerides) is convenient (Abbas et al., 2012; Ugalde et al., 2017).

The definition of wall material to be used is also considered according to the technique that will be used. Each technique has advantages and limitations; therefore, the selection of the most adequate method must take into account all the components of the system as well as the product to be obtained (Abbas et al., 2012). Encapsulation techniques differ in relation to the process involved, and may be chemical, physical or physicochemical.

The choice of technique is based on the desired particle size, application of the final product, physical and chemical properties of the filling and wall material, release mechanism, production scale and cost [114]. Encapsulation techniques involving chemical methods are interfacial polymerization, molecular induction and in-situ polymerization; involving physical methods are extrusion, spray drying, spray chilling, freeze-drying, co-crystallization and fluidized bed; involving physicochemical methods are simple coacervation, complex coacervation, liposomes, and ionic gelation (Jackson \& Lee, 1991; Barreto et al., 2015).

In relation to essential oils, the microencapsulation process provides several benefits, such as protection and stability of volatiles, and storage which makes them applicable in textile, pharmaceutical, cosmetics and food products, whereas in the conventional form the applications are limited due to the volatility of these compounds (Rodríguez et al., 2016). The encapsulation also increases the solubility of EOs, decreasing the need to use surfactants and thus increasing the possibility of using them as food additives. In the microencapsulation of essential oils, it is interesting to use techniques that use low process temperatures, in order to guarantee the loss of a smaller amount of volatiles (Osorio-Tobón et al., 2016).

Spray dryers are drying equipment that use the atomization process of liquids in contact with hot air in a drying chamber. The use of this process dates back to 1870, and at the time of the World Wars there were many technological advances due to the need for non-perishable food for the troops. The spray drying process is composed of four systems: 1) Drying gas and fluid heating system; 2) Atomization system; 3) Drying system; 4) Fines reuse system (Patel et al., 2009).

This spraying and drying process of liquid particles is one of the most used techniques for processes that involve microencapsulation of ingredients (Silva et al., 2014), in particular, of oils and flavors (Fernandes et al., 2017; Yang et al., 2009), since it can be used for drying thermosensitive components (Mishra et al., 2014). This is because the rapid evaporation of water from the polymer matrix during drying and the short time period in which the sample remains in the drying chamber causes it to remain at a temperature below $100^{\circ} \mathrm{C}$, allowing the use of the process in substances thermosensitive (Constant \& Stringheta, 2002). The production cost is low compared to other methods (Böger et al., 2018).

The final particle size obtained by the spray drying method is in the range of a few micrometers. Since the properties of encapsulating agents affect the encapsulation efficiency of oils and flavors, the proper selection of coating material becomes one of the main challenges for microencapsulation. The active modification of matrix components provides improvements in the 
functionality of the particle structures as well as in the stability of the material (Drusch \& Mannino, 2009), and also as in the reconstitution properties, important for these types of products.

One of the prerequisites in the microencapsulation process of essential oil by spray drying is to prepare a stable emulsion with adequate chemical and physical properties, since the stability, properties and composition of the emulsion determine the attributes of microcapsule quality, such as surface free oil content, microencapsulation efficiency, structure, oxidative stability and physical properties (fluidity, density and dispersibility) (Bae \& Lee, 2008). Unstable emulsions lose more volatiles, due to an easier volatilization of non-emulsified materials when atomized (McClements, 2007).

The substance to be encapsulated is homogeneously dissolved in an aqueous solution of the wall material. The mixture is injected into the spray dryer where it is directly atomized through the drying chamber atomizer. The atomized sample comes into contact with a flow of hot air, thus evaporating the solvent and forming small droplets of dry material, in spherical shape. To obtain one material of quality, the hot air inlet and outlet temperatures, inlet air flow, temperature and humidity distribution and drying time must be controlled (Brasileiro, 2011). Agitation is also a relevant parameter in the preparation of the emulsion and interferes on the particle size, as the faster the agitation, the smaller the particles (Lemos, 2017).

The use of the atomization process in microencapsulation has advantages over other methods, being one of the most used techniques for essential oils, as it has stability and efficiency (Jafari et al., 2008), cost effectiveness, speed, formation of high quality microparticles (Shao et al., 2018), good yield, formation of very small particles (smaller than $100 \mu \mathrm{m}$ ), improves solubility, with consequent increase in product stability (Costa et al., 2013), good retention of volatile compounds (Huertas, 2010), and application on industrial scale (Azeredo, 2005). Some characteristics such as colour and flavor can be affected in the atomization process, due to both the material used and the drying parameters (air inlet and outlet temperatures, feed flow, drying speed, among others). Controlling all stages is very important for the efficiency of the process, ensuring the final quality of the product (Lemos, 2017).

The spray drying technique allows a more efficient control of the properties and quality of encapsulated essential oils, since the obtaining processes are optimized, considering the adequate evaluation of the parameters that must be controlled (Reineccius, 2004). One of main causes of the increase in studies involving microencapsulation is due to its use in the controlled release of ingredients and/or additives in foods. Controlled release is defined as a method by which one or more active ingredients are made available at defined time intervals through one or a combination of the following stimuli: change in temperature, humidity or $\mathrm{pH}$, application of pressure or shear, and addition of surfactants (Pothakamury \& Barbosa-Cánova, 1995). The microencapsulation of Cassia cinnamon EOs, which have good antifungal and antibacterial properties, can prolong the shelf life of a food or cereal, as it allows the gradual release of the active (Calo et al., 2015).

Some studies were carried out to evaluate the microencapsulation of cinnamon EOs, where one of them is related to the investigation of a new alternative for the conservation of volatile compounds in cinnamon EO, through spray drying, evaluating the use of different materials encapsulants in relation to their physicochemical properties. The use of gum arabic and protein isolate as wall material, in addition to their combination with maltodextrin, were investigated. All materials investigated proved to be suitable for microencapsulation of cinnamon EO (Felix, 2014). Hu et al. (2020) evaluated the microcapsule retention capacity of cinnamon EO, obtained by spray drying, using as wall materials isolated from whey protein, maltodextrin and sodium alginate, where they obtained a rate of retention of more than $95 \%$ of EO in microcapsules during storage at $50{ }^{\circ} \mathrm{C}$ for 30 days. Other essential oils were microencapsulated with spray drying technique, as shown in Table 1. 
Table 1 - Microencapsulation of essential oils with spray drying technique.

\begin{tabular}{|c|c|c|}
\hline Essential Oil & Wall material & Reference \\
\hline Avocado essential oil & $\begin{array}{l}\text { Modified maltodextrin with octenyl succinic } \\
\text { anhydride }\end{array}$ & $\begin{array}{l}\text { Sotelo-Bautista et al. } \\
\qquad(2020)\end{array}$ \\
\hline Refined Kenaf (Hibiscus cannabinus) seed oil & $\begin{array}{c}\text { Arabic gum, cyclodextrin and sodium } \\
\text { caseinate }\end{array}$ & Chew et al. (2020) \\
\hline $\begin{array}{c}\text { Lemongrass essential oil (Cymbopogon } \\
\text { flexuosus) }\end{array}$ & Arabic gum and maltodextrin & Melo et al. (2020) \\
\hline $\begin{array}{l}\text { Rosewood and Cinnamon essential oil } \\
\text { (Cinnamomun Cassia) }\end{array}$ & $\begin{array}{l}\text { Poly (butylene adipate co-terephthalate) } \\
\qquad \text { (Pbat) and Tween } 80\end{array}$ & Barbosa et al. (2021) \\
\hline $\begin{array}{l}\text { Cinnamon essential oil (Cinnamomum } \\
\text { zeylanicum, } 75 \% \text { of eugenol e } 1 \% \text { de } \\
\text { cinnamaldehyde) }\end{array}$ & Sodium alginate & Makimori et al. (2020) \\
\hline $\begin{array}{l}\text { Cinnamon essential oil (Cinnamomum } \\
\text { zeylanicum, cinnamaldehyde as major } \\
\text { compound) }\end{array}$ & $\begin{array}{l}\text { Arabic gum/maltodextrin; arabic gum/Inulin; } \\
\text { gum arabic; maltodextrin/inulin }\end{array}$ & $\begin{array}{l}\text { Noghabi \& Molaveisi } \\
\qquad(2020)\end{array}$ \\
\hline $\begin{array}{c}\text { Cinnamon essential oil (Cinnamomum } \\
\text { zeylanicum) }\end{array}$ & $\begin{array}{l}\text { Persia gum/maltodextrin } \\
\qquad(2: 8 \% \mathrm{~m}: \mathrm{m})\end{array}$ & Luong-Van et al. (2020) \\
\hline Cinnamon essential oil (Cinnamomum cassia) & $\begin{array}{c}\text { Whey protein, maltodextrin and sodium } \\
\text { alginate }\end{array}$ & Hu et al. (2020) \\
\hline
\end{tabular}

Source: Authors.

\section{Final Considerations}

There is a growing interest in use of essential oils in the prevention and control of insect pests in stored grain, as noted in this literature review. The increase in this interest is due to the search for natural and less risky alternatives to older insecticide molecules, often involving the use of new molecules and especially natural insecticides, also called biopesticides, which cause less harm to human health, in this exchange, besides being biodegradable.

The high content of bioactive compounds in EOs is what gives them biological activity, making most aromatic plants rich in EOs to be potential as an insecticide, repellent or food deterrent, and antimicrobial agent. Another important compound characteristic is a natural bioactive ability against pests, arising from the correct evolutionary development in defense and in response to possible ones. Thus, EOs are an excellent alternative to control and reduce losses by pests in the grain storage.

EOs such as cinnamon (C. cassia) contain the active ingredients responsible for their antifungal and insecticidal properties. From the genus Cinnamomum, the species C. zeylanicum, C. loureirri, C. burmanni and C. cassia are the most used and, therefore, the most studied. However, information regarding the use of these species as antifungal, insecticide and repellent, both in free and encapsulated form, in combating and controlling fungi and insects in maize stored grains is scarce.

Studies have shown the importance of techniques such as microencapsulation in the stability and retention of aromatic compounds in EOs. Among the microencapsulation techniques, the spray drying technique is economical and flexible, producing good quality particles, with good retention of volatiles and good stability of the final product. However, there is little information in the literature on the microencapsulation of cinnamon EOs, evidencing a vast field of research that needs to be explored to enable the use of cinnamon EOs as insecticides, antifungal and natural repellents to maize weevil (S. zeamais) in stored grains. 
In this sense, basic and applied research to demonstrate the simultaneous insecticidal, repellent and antifungal potential of essential oils for application in stored grains, as well as alternatives to minimize their losses by volatilization and evaluation of grain quality and possible sensory changes, are necessary and current.

\section{Acknowledgments}

This study was financed in part by the National Council for Scientific and Technological Development - Brazil (CNPq), Coordination for the Improvement of Higher Education Personnel - Brazil (CAPES) and Research Support Foundation of the State of Rio Grande of Sul - Brazil (FAPERGS).

\section{References}

Abbas, S.; Da Wei, C.; Hayat, K. \& Xiaoming, Z. (2012). Ascorbic Acid: Microencapsulation Techniques and Trends-A Review. Food Rev. Int., $28,343-374$. https://doi.org/10.1080/87559129.2011.635390.

Andrade-Ochoa, S.; Nevárez-Moorillón, G. V.; Sánchez-Torres, L. E.; Villanueva-García, M.; Sánchez-Ramírez, B. E.; Rodríguez-Valdez, L. M. \& RiveraChavira, B. E. (2015). Quantitative structure-activity relationship of molecules constituent of different essential oils with antimycobacterial activity against Mycobacterium tuberculosis and Mycobacterium bovis. BMC Complement Altern. Med., 15, 332. https://doi.org/10.1186/s12906-015-0858-2.

Andrés, M. F.; González-Coloma, A.; Sanz, J.; Burillo, J. \& Sainz, P. (2012). Nematicidal activity of essential oils: a review. Phytochem. Rev., 11, 371-390. https://doi.org/10.1007/s11101-012-9263-3.

Attokaran, M. (2017). Turmeric: Curcuma longa L (Zingiberaceae). Natural Food Flavors and Colorants. Ames: Backwell Publishing Ltd and Inst. Food Technol., 98, 391-39.

Azeredo, H. M. C. ((2005). Encapsulação: aplicação à tecnologia de alimentos. Alim. Nutr., 16, 89-97.

Bae, E. K. \& Lee, S. J. (2008). Microencapsulation of avocado oil by spray drying using whey protein and maltodextrin. J. Microencapsul., 25, 549-560. https://doi.org/10.1080/02652040802075682.

Bakkali, F.; Averbeck, S.; Averbeck, D. \& Idaomar, M. (2008). Biological effects of essential oils - A review. Food Chem. Toxicol., 46, 446-475. https://doi.org/10.1016/j.fct.2007.09.106.

Barbosa, R. F. S.; Yudice, E. D. C.; Mitra, S. K. \& Rosa, D. S. (2021). Characterization of Rosewood and Cinnamon cassia essential oil polymeric capsules: Stability, loading efficiency, release rate and antimicrobial properties. Food Control, 121, 107605. https://doi.org/10.1016/j.foodcont.2020.107605.

Barreto, A. R.; Ramírez-Mérida, L. G.; Etchepare, M. de A.; Jacob-Lope, E. \& Menezes, C. R. (2015). Materiais de revestimento utilizados na microencapsulação de probióticos. Ciência e Natura, 37, 164-174. https://doi.org/10.5902/2179-460X19747.

Benelli, G. (2015). Research in mosquito control: current challenges for a brighter future. Parasitol. Res., 114, 2801-2805. https://doi.org/10.1007/s00436-0154586-9.

Bennett, J. W. \& Klich, M. (2003). Mycotoxins. J. Clin. Microbiol., 16(3), 497-516. http://dx.doi.org/10.1128/cmr.16.3.497-516.2003.

Betancur, J. R.; Silva, G. A.; Rodríguez, C. J. M.; Fischer, S. G. \& Zapata, N. S. M. (2010). Insecticidal Activity of Peumus boldus Molina Essential Oil against Sitophilus zeamais Motschulsky. Chil. J. Agric. Res., 70, 399-407.

Böger, B. R.; Georgetti, S. R. \& Kurozawa, L. E. (2018). Microencapsulation of grape seed oil by spray drying. Food Sci. Technol., 38, $263-270$.

Boyer, S.; Zhang, H. \& Lempérière, G. (2012). A review of control methods and resistance mechanisms in stored-product insects. Bull. Entomol. Res., 102, 21322. https://doi.org/10.1017/S0007485311000654.

Brasileiro, J. S. L. (2011). Microencapsulação de compostos bioactivos: inovação em diferentes áreas. Dissertação. Mestrado Integrado em Ciências Farmacêuticas. Universidade Fernando Pessoa. http://hdl.handle.net/10284/2457.

Burt, S. (2004). Essential oils: their antibacterial properties and potential applications in foods-a review. Int. J. Food Microbiol., 94, 223-253. https://doi.org/10.1016/j.ijfoodmicro.2004.03.022.

Calo, J. R.; Crandall, P. G.; O’bryan, C. A. \& Ricke, S. C. (2015). Essential oils as antimicrobials in food systems- A review. Food Control, 54, 111-119. https://doi.org/10.1016/j.foodcont.2014.12.040.

Cansian, R. L.; Vanin, A. B.; Orlando, T.; Piazza, S. P.; Puton, B. M. S.; Cardoso, R. I.; Gonçalves, I. L.; Honaiser, T. C.; Paroul, N. \& Oliveira, D. (2017). Toxicity of clove essential oil and its ester eugenyl acetate against Artemia salina. Braz. J. Biol, 77, 155-161. https://doi.org/10.1590/1519-6984.12215

Cansian, R. L.; Astolfi, V.; Cardoso, R. I.; Paroul, N.; Roman, S. S.; Mielniczki-Pereira, A. A.; Pauletti, G. F. \& Mossi, A. J. (2015). Insecticidal and repellent activity of the essential oil of Cinnamomum camphora var. linaloolifera Y. Fujita (Ho-Sho) and Cinnamomum camphora (L.) J Presl. var. hosyo (Hon-Sho) on Sitophilus zeamais Mots. (Coleoptera, Curculionedae). Rev Bras Pl Med., 17, 769-773.

Casida, J. E. \& Durkin, K. A. (2013). Anticholinesterase insecticide retrospective. Chem. Biol. Interact., 203, 221-225. https://doi.org/10.1016/j.cbi.2012.08.002. 
Chew, S.-C.; Tan, C.-P.; Tan, C.-H. \& Nyam, K.-L. (2020). In-vitro bioaccessibility of spray dried refined kenaf (Hibiscus cannabinus) seed oil applied in coffee drink. J. Food Sci. Technol., 7, 2507-2515. https://doi.org/10.1007/s13197-020-04286-9.

Chiozza, L. (1856). Sur la production artificielle de l'essence de cannelle"[on the artificial production of cinnamon oil]. Omptes rendus [in French], 222-227. Chu, S. S., Du, S. S. \& Liu, Z. L. (2013). Fumigant compounds from the essential oil of Chinese Blumea balsamifera leaves against the maize weevils (Sitophilus zeamais). J. Chem., 2013, 289874. https://doi.org/10.1155/2013/289874.

Conab. (2021). Levantamento Sistemático da Produção Agrícola - LSPA. <https://www.ibge.gov.br/estatisticas/economicas/agricultura-e-pecuaria/9201levantamento-sistematico-da-producao-agricola.html?=\&t=resultados>

Constant, P. B. L. \& Stringheta, P. C. (2002). Microencapsulação de ingredientes alimentícios. Sociedade Brasileira de Ciência e Tecnologia de Alimentos, 36, $12-18$.

Corrêa, J. C. R. \& Salgado, H. R. N. (2011). Atividade inseticida das plantas e aplicações: revisão. Rev. Bras. de Plantas Medicinais, 13, 500-506. https://doi.org/10.1590/S1516-05722011000400016.

Cosimi, S.; Rossi, E.; Cioni, P. L. \& Canale, A. (2009). Bioactivity and qualitative analysis of some essential oils from Mediterranean plants against storedproduct pests: Evaluation of repellency against Sitophilus zeamais Motschulsky, Cryptolestes ferrugineus (Stephens) and Tenebrio molitor (L.). J. Stored Prod. Res., 45, 125-132. https://doi.org/10.1016/j.jspr.2008.10.002.

Costa, A.F. (2002). Farmacognosia. Lisboa, Fundação Calouste Gulbenkian. 6ed. v. 3, p. 1-37.

Costa, J. M. G.; Borges, S. V.; Hijo, A. A. C. T.; Silva, E. K.; Marques, G. R.; Cirillo, M. Â. \& Azevedo, V. M. (2013). Matrix structure selection in the microparticles of essential oil oregano produced by spray dryer. J Microencapsul, 30, 717-727. https://doi.org/10.3109/02652048.2013.778909.

Costa, M. L. N.; Gonçalves, D. S. F. \& Machado, J. C. (2020). Controle de Fusarium verticillioides em sementes de milho com o óleo essencial de gengibre. Summa Phytopathol., 46, 250-254. https://doi.org/10.1590/0100-5405/233888.

Desai, K. G. H. \& Park, H. J. (2005). Encapsulation of vitamin C in tripolyphosphate cross-linked chitosan microspheres by spray drying. J. Microencapsul, 22, 179-192. https://doi.org/10.1080/02652040400026533.

Devi, N.; Sarmah, M.; Khatun, B. \& Maji, T. K. (2017). Encapsulation of active ingredients in polysaccharide-protein complex coacervates. Adv. Colloid Interface Sci., 239, 136-145. https://doi.org/10.1080/02652040400026533.

Doebley, J. (1990). Molecular evidence for gene flow among Zea species. Biosci, 40, 443-448. https://doi.org/10.2307/1311391.

Drusch, S. \& Mannino, S. (2009). Patent-based review on industrial approaches for the microencapsulation of oils rich in polyunsaturated fatty acids. Trends Food Sci Technol, 20, 237-244. https://doi.org/10.1016/j.tifs.2009.03.007.

Duarte, J. $\quad$ O.; $\quad$ Mattoso, M. J. $\quad$ \& $\quad$ Garcia, J. $\quad$ C. $\quad$ (2010) Economia da https://www.agencia.cnptia.embrapa.br/gestor/milho/arvore/CONTAG01_8_168200511157.html, accessed on: 01/03/2020.

Duguta, M. T. \& Cheryan, D. B. (2021). An Introduction and Various Phytochemical Studies of Cinnamomum malabatrum: A Brief Review. Pharmacogn. J., 13, 792-797. https://doi.org/10.5530/pj.2021.13.101.

Dumas, J. \& Peligot, H. (1834). Sur 1'Huile de Cannelle, l'Acide Hippurique, e l'Acide Sébacique. Annales de chimie et de physique, 57, 305-334.

Fancelli, A. L. (2015). Manejo baseado na fenologia aumenta a eficiência de insumos e produtividade. Cadeia produtiva do milho. Revista Visão Agrícola. Escola Superior de Agricultura Luiz de Queiroz. Ano 9, p. 25.

Faroni, L. R. A.; Heleno, F. F. \& Ávila, M. B. R. (2014). Resíduos de Pesticidas em Grãos no Brasil. In: Pós-Colheita de Grãos: Logística e Segurança Alimentar do Produtor ao Consumidor. 1 ed. Londrina: ABRAPOS, v.6, p. 44-52.

Fassio, D. M. R.; Souza, A. B. M.; Medeiros, S. T. \& Thomé, R. P. (2018). Otimização da infraestrutura logística na mitigação de perdas na pós-colheita de grãos. In: Perdas e desperdício de alimentos: estratégias para redução. Brasília, DF: Câmara dos Deputados, 1, $115-131$.

Fávaro-Trindade, C. S.; Pinho, S. C. \& Rocha, G. A. (2008). Revisão: microencapsulação de ingredientes alimentícios (2008). Brazilian J. Food Technol., 11, $103-112$.

Felix, P. H. C. (2014). Microencapsulação de óleo essencial de canela por atomização com emprego de diferentes materiais de parede. Universidade Federal de Minas Gerais. http://hdl.handle.net/1843/BUBD-9WRJ69.

Fernandes, R.; Carmo, E.; Borges, S.; Botrel, D.; Silva, Y. \& Souza, H. (2017). Comportamento de óleo essencial de alecrim microencapsulado por spray drying em diferentes umidades relativas. Revista Ciência Agrícola, 14, 73. https://doi.org/10.28998/rca.v14i1.2469.

Friedman, M.; Kozuke, N. \& Harden, L. A. (2000). Cinnamaldehyde content in foods determined by gas chromatography-mass spectrometry. J. Agric. Food Chem., 48, 5702-5709. https://doi.org/10.1021/jf000585g.

Gallo, D.; Nakano, O.; Silveira Neto, S.; Carvalho, R. P. L.; Batista, G. C.; Berti Filho, E.; Parra, J. R. P.; Zucchi, R. A.; Alves, S. B.; Vendramin, J. D.; Marchini, L. C.; Lopes, J. R. S. \& Omoto, C. (2002). Entomologia agrícola. Piracicaba: FEALQ, p. 920.

Gill, A. O. \& Holley, R. A. (2004). Mechanisms of Bactericidal Action of Cinnamaldehyde against Listeria monocytogenes and of Eugenol against L. monocytogenes and Lactobacillus sakei. Appl. Environ. Microbiol., 70, 5750-5755. https://doi.org/10.1128/AEM.70.10.5750-5755.2004.

Gonçalves, V. D. M.; Huerta, M. \& Freitag, R. A. (2016). Potencial de plantas acaricidas no controle de carrapatos Rhipicephalus (Boophilus) microplus. Rev. Ciên. Vet. Saúde Públ, 3, 14. https://doi.org/10.4025/revcivet.v3i1.29096. 
Goneli, A. L. D. (2021). Novas tecnologias aplicadas à pós-colheita para mitigação de perdas qualitativas e quantitativas. In: Perdas em transporte e armazenagem de grãos: panorama atual e perspectivas. Brasília, DF: Conab, p. 75-86.

Hamzah, H.; Indra Yudhawan, I.; Nur Rasdianah, N.; Setyowati, E.; Erika Nandini, E. \& Pratiwi, S. U. T. (2022). Clove Oil Has the Activity to Inhibit Middle, Maturation and Degradation Phase of Candida tropicalis Biofilm Formation. Biointerface Res Appl. Chem, 12(2), 1507-1519. https://doi.org/10.33263/BRIAC122.15071519

Hernandez Nopsa, J. F.; Daglish, G. J.; Hagstrum, D. W.; Leslie, J. F.; Phillips, T. W.; Scoglio, C.; Thomas-Sharma, S.; Walter, G. H. \& Garrett, K. A. (2015). Ecological Networks in Stored Grain: Key Postharvest Nodes for Emerging Pests, Pathogens, and Mycotoxins. Biosci, 65, 985-1002. https://doi.org/10.1093/biosci/biv122.

Hu, Q.; Li, X.; Chen, F.; Wan, R.; Yu, C.; Li, J. \& Deng, Z. (2020). Microencapsulation of an Essential Oil (Cinnamon Oil) by Spray Drying: Effects of Wall Materials and Storage Conditions on Microcapsule Properties. J. Food Process. Pres., 44, 14805-14816. https://doi.org/10.1111/jfpp.14805.

Huang, Y.; Tan, J. M. W. L.; Kini, R. M. \& Ho, S. H. (1997). Toxic and antifeedant action of nutmeg oil against Tribolium castaneum (Herbst) and Sitophilus zeamais Motsch. J. Stored Prod. Res., 33, 289-298. https://doi.org/10.1016/S0022-474X(97)00009-X.

Huertas, R. A. P. (2010). Revisión: Microencapsulación de Alimentos. Rev. Fac. Nac. Agron. Medellin., 63, 5669-5684.

Isman, M. B. \& Grieneisen, M. L. (2014). Botanical insecticide research: many publications, limited useful data. Trends Plant Sci., 19, 140-145. https://doi.org/10.1016/j.tplants.2013.11.005.

Isman, M. B. (2000). Plant essential oils for pest and disease management. Crop Prot, 19, 603-608. https://doi.org/10.1016/S0261-2194(00)00079-X.

Isman, M. B. (2006). Botanical insecticides, deterrents, and repellents in modern agriculture and an increasingly regulated world. Rev. Entomol., 51, 45-66. https://doi.org/10.1146/annurev.ento.51.110104.151146.

Jackson, L. S. \& Lee, K. (1991). Microencapsulation and food industry. Lebensm.-Wiss. u.-Technol., 24, 289-297.

Jafari, S. M.; Assadpoor, E.; He, Y. \& Bhandari, B. (2008). Encapsulation Efficiency of Food Flavours and Oils during Spray Drying. Dry. Technol., 26, 816835. https://doi.org/10.1080/07373930802135972.

Jankowska, M.; Rogalska, J.; Wyszkowska, J. \& Stankiewicz, M. (2017). Molecular Targets for Components of Essential Oils in the Insect Nervous SystemA Review. Molecules, 23, 34. https://doi.org/10.3390/molecules23010034.

Jardim, I. C. S. F.; Andrade, J. de A. \& Queiroz, S. C. do N. (2009). Resíduos de agrotóxicos em alimentos: uma preocupação ambiental global - Um enfoque às maçãs. Quim. Nova., 32, 996-1012. https://doi.org/10.1590/S0100-40422009000400031.

Kim, S.-I.; Roh, J.-Y.; Kim, D.-H.; Lee, H.-S. \& Ahn, Y.-J. (2003). Insecticidal activities of aromatic plant extracts and essential oils against Sitophilus oryzae and Callosobruchus chinensis. J. Stored Prod. Res., 39, 293-303, https://doi.org/10.1016/S0022-474X(02)00017-6.

Knaak, N. \& Fiuza, L. M. (2010). Potencial dos óleos essenciais de plantas no controle de insetos e microrganismos. Neotrop. Biol. Conserv., 5, 120-132.

Koul, O.; Walia, S. \& Dhaliwal, G. S. (2008). Essential Oils as Green Pesticides: Potential and Constraints. Biopesticide Int., 4, 63-84.

Lee, R. \& Balick, M. J. (2005). Sweet wood-cinnamon and its importance as a spice and medicine. Explore, 1, 61-64. https://doi.org/10.1016/j.explore.2004.10.011.

Lemos, Y. P. (2017). Microencapsulação de óleo de buriti por coacervação complexa em matrizes de gelatina/alginato. Dissertação (Mestrado em Engenharia de alimentos) - Universidade Estadual Paulista "Júlio de Mesquita Filho", Campus de São José do Rio Preto. http://hdl.handle.net/11449/150282.

Lima, M. P.; Zoghbi, M. G. B.; Andrade, E. H. A.; Silva, T. M. D. \& Fernandes, C. S. (2005). Constituintes voláteis das folhas e dos galhos de Cinnamomum zeylanicum Blume (Lauraceae). Acta Amaz., 35, 363-366. https://doi.org/10.1590/S0044-59672005000300009.

López-Mata, M. A.; Ruiz-Cruz, S.; Ornelas-Paz, J. J.; Del Toro-Sánchez, C. L.; Márquez-Ríos, E.; Silva-Beltrán, N. P.; Cira-Chávez, L. A. \& Burruel-Ibarra, S. E. (2018). Mechanical, Barrier and Antioxidant Properties of Chitosan Films Incorporating Cinnamaldehyde. J. Polym. Environ., 26, 452-461. https://doi.org/10.1007/s10924-017-0961-1

Lorini, I.; Krzyzanowski, F. C.; França-Neto, J. DE B.; Henning, A. A. \& Henning, F. A. (2015). Manejo Integrado de Pragas de Grãos e Sementes Armazenadas. 1nd ed.; Brasília, DF: Embrapa 2015, p. 84.

Luong-Van, E. K.; Madanagopal, T. T. \& Rosa, V. (2020). Mechanisms of graphene influence on cell differentiation. Mater. Today Chem., 16, 100250. https://doi.org/10.1016/j.mtchem.2020.100250.

Maciel, L.M. \& Tunes, L.V.M. (2021). A importância no controle de qualidade nas sementes de milho. BJD,. 7, 49934. https://doi.org/10.1016/j.mtchem.2020.100250.

Mahesh S.; Narasaiah, B. P.; Mandal, B. K. \& Balaji, G. L. (2022). Fabrication of Titanium Dioxide Nanoparticles Using Sunflower Leaf Extract and Their Applications Towards the Synthesis and Biological Evaluation of Some Novel Phenanthro Imidazole Derivatives. Biointerface Res Appl. Chem, 12(3), 33723389. https://doi.org/10.33263/BRIAC123.33723389

Maia, M. F. \& Moore, S. J. (2011). Plant-based insect repellents: a review of their efficacy, development and testing. Malar. J., 10, S11. https://doi.org/10.1186/1475-2875-10-S1-S11. 
Makimori, R. Y.; Endo, E. H.; Makimori, J. W.; Zanqueta, E. B.; Ueda-Nakamura, T.; Leimann, F. V.; Gonçalves, O. H. \& Dias Filho, B. P. (2020). Preparation, characterization and antidermatophytic activity of free- and microencapsulated cinnamon essential oil. J. Mycol. Med., 30 , 100933. https://doi.org/10.1016/j.mycmed.2020.100933.

Mannaa, M. \& Kim, K. D. (2017). Influence of temperature and water activity on deleterious fungi and mycotoxin production during grain storage. Mycobiology, 45, 240-254. https://doi.org/10.5941/MYCO.2017.45.4.240.

Mapa (2020). Ministério da Agricultura Pecuária e Abastecimento. Agrofit - Sistema de agrotóxicos fitossanitários. <http://extranet.agricultura.gov.br/agrofit_cons/!ap_praga_detalhe_cons?p_id_cultura_praga=3233>

Markellou, E.; Kalamarakis, A. E.; Kasselaki, A. M.; Dafermos, N.; Toufexi, E.; Leifert, C.; Karamaouna, F. \& Konstantinidou-Doltsinis, S. (2009). Potential use of botanical fungicides against grey mould and powdery mildew in greenhouse grown vegetables. IOBC/WPRS Bulletin, 61-66.

Mathew, S. \& Abraham, T. E. (2006). In vitro antioxidant activity and scavenging effects of Cinnamomum verum leaf extract assayed by different methodologies. Food Chem Toxicol, 44, 198-206. https://doi.org/10.1016/j.fct.2005.06.013.

McClements, D. J. (2007). Critical review of techniques and methodologies for characterization of emulsion stability. Crit. Rev. Food Sci. Nutr., 47, 611-649. https://doi.org/10.1080/10408390701289292.

Melo, A. M.; Turola Barbi, R. C.; Souza, W. F. C.; Luna, L. C.; Souza, H. J. B.; Lucena, G. L.; Quirino, M. R. \& Sousa, S. Microencapsulated lemongrass (Cymbopogon flexuosus) essential oil: A new source of natural additive applied to Coalho cheese. J. Food Process. Pres., 44 , e14783. https://doi.org/10.1111/jfpp.14783.

Mesterházy, A.; Oláh, J. \& Popp, J. (2020). Losses in the Grain Supply Chain: Causes and Solutions. Sustainability, 12(6), 2342. https://doi.org/10.3390/su12062342.

Mishra, P.; Mishra, S. \& Mahanta, C. L. (2014). Effect of maltodextrin concentration and inlet temperature during spray drying on physicochemical and antioxidant properties of amla (Emblica officinalis) juice powder. Food Bioproc. Tech., 92, 252-258. https://doi.org/10.1016/j.fbp.2013.08.003.

Mithöfer, A. \& Boland, W. (2012). Plant Defense Against Herbivores: Chemical Aspects. Annu Rev Phytopathol, 63, 431-450. https://doi.org/10.1146/annurevarplant-042110-103854.

Mossi, A. J.; Astolfi, V.; Kubiak, G.; Lerin, L.; Zanella, C.; Toniazzo, G.; Oliveira, D.; Treichel, H.; Devilla, I. A.; Cansian, R. \& Restello, R. (2011). Insecticidal and repellency activity of essential oil of Eucalyptus sp. against Sitophilus zeamais Motschulsky (Coleoptera, Curculionidae). J Sci Food Agric., 91, $273-277$. https://doi.org/10.1002/jsfa.4181.

Mossi, A. J.; Zanella, C. A. ; Kubiak, G.; Lerin, L. A. ; Cansian, R. L.; Frandoloso, F. S.; Dal Prá, V.; Mazutti, M. A.; Costa, J. A. V. \& Treichel, H. (2014). Essential oil of Ocotea odorifera: An alternative against Sitophilus zeamais. Renew Agric Food Syst., 29, 161-166. https://doi.org/10.1017/S1742170513000045

Naqqash, M. N.; Gökçe, A.; Bakhsh, A. \& Salim, M. (2016). Insecticide resistance and its molecular basis in urban insect pests. Parasitol. Res., 115, 13631373. https://doi.org/10.1007/s00436-015-4898-9.

Nerio, L. S.; Olivero-Verbel, J. \& Stashenko, E. E. (2009). Repellent activity of essential oils from seven aromatic plants grown in Colombia against Sitophilus zeamais Motschulsky (Coleoptera). J. Stored Prod. Res., 45, 212-214. https://doi.org/10.1016/j.jspr.2009.01.002.

Noghabi, M. S. \& Molaveisi, M. (2020). The effect of wall formulation on storage stability and physicochemical properties of cinnamon essential oil microencapsulated by spray drying. Chem. Zvesti, 74, 3455-3465. https://doi.org/10.1007/s11696-020-01171-9.

Nwanade, C. F.; Wang, M.; Wang, T.; Zhang, X.; Zhai, Y. \& Zhang, S. (2021). The acaricidal activity of cinnamon essential oil: current knowledge and future perspectives. Int J Acarology, 47, 446-450. https://doi.org/10.1080/01647954.2021.1936632.

Ojeda-Sana, A. M.; Van Baren, C. M.; Elechosa, M. A.; Juárez, M. A. \& Moreno, S. (2013). New insights into antibacterial and antioxidant activities of rosemary essential oils and their main components. Food Control, 31, 189-195. https://doi.org/10.1016/j.foodcont.2012.09.022.

Osorio-Tobón, J. F.; Silva, E. K. \& Meireles, M. A. A. (2016). Nanoencapsulation of flavors and aromas by emerging technologies. In: Encapsulations. Elsevier, Campinas, São Paulo, Brazil, p. 89-126. https://doi.org/10.1016/B978-0-12-804307-3.00003-X.

Papachristos, D. P. \& Stamopoulos, D. C. (2002). Repellent, toxic and reproduction inhibitory effects of essential oil vapours on Acanthoscelides obtectus (Say) (Coleoptera: Bruchidae). J. Stored Prod. Res., 38, 117-128. https://doi.org/10.1016/S0022-474X(01)00007-8.

Pascual-Villalobos, M. J. (1996). Evaluation of insecticidal activity of Chrysanthemum coronarium L., plant extracts. Boletin de Sanidad, 22, 411-420.

Patel, R. P.; Patel, M. P. \& Suthar, A. M. (2009). Spray drying technology: an overview. Indian. J. Sci. Technol., 2, $44-47$.

Patriarca, A. \& Pinto, V. F. (2017). Prevalence of mycotoxins in foods and decontamination. Curr. Opin. Food Sci, 14, 50-60. https://doi.org/10.1016/j.cofs.2017.01.011.

Pavela, R. \& Benelli, G. (2016). Essential Oils as Ecofriendly Biopesticides? Challenges and Constraints. Trends Plant Sci., 21, 1000-1007. https://doi.org/10.1016/j.tplants.2016.10.005.

Pavela, R. (2016). History, presence and perspective of using plant extracts as commercial botanical insecticides and farm products for protection against insects - a review. Plant Protect. Sci., 52, 229-241. https://doi.org/10.17221/31/2016-PPS.

Pereira, C. A. M. \& Maia, J. F. (2007). Estudo da atividade antioxidante do extrato e do óleo essencial obtidos das folhas de alfavaca (Ocimum gratissimum L.). Ciênc. Tecnol. Aliment., 27, 624-632. https://doi.org/10.1590/S0101-20612007000300030. 
Pothakamury, U. R.; Barbosa-Cánova, G. V. (1995). Fundamental aspects of controlled release in foods. Trends Food Sci. Technol., 6, 397-406. https://doi.org/10.1016/S0924-2244(00)89218-3.

Prestes, I.; Rocha, L.; Nuñez, K. \& Silva, N. (2019). Fungi and mycotoxins in corn grains and their consequences. Sci. Agric., 10, 559-570. https://doi.org/10.17268/sci.agropecu.2019.04.13.

Rattan, R. S. (2010). Mechanism of action of insecticidal secondary metabolites of plant origin. Crop Prot., 29, 913-920. https://doi.org/10.1016/j.cropro.2010.05.008.

Regnault-Roger, C.; Vincent, C. \& Arnason, J. T. (2012). Essential Oils in Insect Control: Low-Risk Products in a High-Stakes World. Annu. Rev. Entomol., 57, 405-424. https://doi.org/10.1146/annurev-ento-120710-100554.

Reineccius, G. A. (2004). The Spray Drying of Food Flavors. Dry Technol., 22, 1289-1324. https://doi.org/10.1081/DRT-120038731.

Ribeiro-Santos, R.; Andrade, M.; De Melo, N. R.; Dos Santos, F. R.; Neves, I. A.; De Carvalho, M. G. \& Sanches-Silva, A. (2017). Biological activities and major components determination in essential oils intended for a biodegradable food packaging. Ind. Crops Prod., 97, 201-210. https://doi.org/10.1016/j.indcrop.2016.12.006.

Rocha, M. P.; Taveira, J. H. Da S.; Prado, S. M. A. \& Ataíde, M. V. (2020). Sistema de armazenamento e incidência dos principais fungos produtores de micotoxinas em grãos. BJD, 6, 50176-50193. https://doi.org/10.34117/bjdv6n7-608.

Rodrigues, I.; Handl, J. \& Binder, E. M. (2011). Mycotoxin occurrence in commodities, feeds and feed ingredients sourced in the Middle East and Africa. Food Addit. Contam. Part B Surveill., 4, 168-179. https://doi.org/10.1080/19393210.2011.589034.

Rodríguez, J.; Martín, M. J.; Ruiz, M. A. \& Clares, B. (2016). Current encapsulation strategies for bioactive oils: From alimentary to pharmaceutical perspectives. Food. Res. Int., 83, 41-59. https://doi.org/10.1016/j.foodres.2016.01.032.

Roel, A. R. (2001). Utilização de plantas com propriedades inseticidas: uma contribuição para o desenvolvimento rural sustentável. Interações (Campo Grande), 1, 43-50. https://doi.org/10.20435/inter.v22i1.2856.

Rohwer, J. G. (1993). Lauraceae. In: Kubitzki, K.; Rohwer, J. G. \& Bittrich, V. (eds) The families and genera of vascular plants. Magnoliid, hamamelid and caryophyliid families. Berlin, Springer - Verlag, v. 2, p. 336-391.

Saito, M. L.; Pott, A.; Ferraz, J. M. G. \& Nascimento, R. D. S. (2004). Avaliação de plantas com atividade deterrente alimentar em Spodoptera frugiperda (J.E. Smith) e Anticarsia gemmatalis Hubner. Pesticidas: R. Ecotoxicol. e Meio Ambiente, 14.

Santos, J. C. dos; Faroni, L. R. D.; Simões, R. de O.; Pimentel, M. A. G. \& Sousa, A. H. (2009). Toxicidade de inseticidas piretróides e organofosforados para populações brasileiras de Sitophilus zeamais (Coleoptera: Curculionidae). Biosci. J., 25, 75-81.

Santos, J. P. (2006). Inovações técnicas para armazenamento de milho na propriedade familiar. In: XXVI Congresso Nacional de Milho e Sorgo. 1nd ed. EMBRAPA, Milho e Sorgo. Minas Gerais, p. 2.

Schiper, L.P. (1999). Segredos e virtudes das plantas medicinais. Rio de Janeiro: Reader's Digest Brasil.

Schmidt, G. H. \& Streloke, M. (1994). Effect of Acorus calamus (L.) (Araceae) oil and its main compound $\beta$-asarone on Prostephanus truncatus (Horn) (Coleoptera: Bostrichidae). J. Stored Prod. Res., 30, 227-235. https://doi.org/10.1016/0022-474X(94)90050-R.

Shao, W.; Pan, X.; Liu, S.; Teng, F. \& Yuan, S. (2018). Microencapsulation of algal oil using spray drying technology. Food Technol. Biotechnol., 56, 65-70. https://doi.org/10.17113/ftb.56.01.18.5452.

Shen, F.; Huang, Y.; Jiang, X.; Fang, Y.; Li, P.; Liu, Q.; Hu, Q. \& Liu, X. (2020). On-line prediction of hazardous fungal contamination in stored maize by integrating Vis/NIR spectroscopy and computer vision. Spectrochim. Acta A Mol., 229, 118012. https://doi.org/10.1016/j.saa.2019.118012.

Shishir, M. R. I.; Xie, L.; Sun, C.; Zheng, X. \& Chen, W. (2018). Advances in micro and nano-encapsulation of bioactive compounds using biopolymer and lipid-based transporters. Trends Food Sci. Technol., 78, 34-60. https://doi.org/10.1016/j.tifs.2018.05.018.

Silva, E. K.; Fernandes, R. V. B.; Borges, S. V.; Botrel, D. A. \& Queiroz, F. (2014). Water adsorption in rosemary essential oil microparticles: Kinetics, thermodynamics and storage conditions. J. Food Eng., 140, 39-45. https://doi.org/10.1016/j.jfoodeng.2014.05.003.

Singh, G.; Maurya, S.; Delampasona, M. P. \& Catalan, C. A. N. (2007). A comparison of chemical, antioxidant and antimicrobial studies of cinnamon leaf and bark volatile oils, oleoresins and their constituents. Food Chem Toxicol, 45, 1650-1661. https://doi.org/10.1016/j.fct.2007.02.031.

Sonker, N.; Pandey, A. K. \& Singh, P. (2014). Efficiency of Artemisia nilagirica (Clarke) Pamp. essential oil as a mycotoxicant against postharvest mycobiota of table grapes. J. Sci. Food Agric., 95, 1932-1939. https://doi.org/10.1002/jsfa.6901.

Sotelo-Bautista, M.; Bello-Perez, L. A.; Gonzalez-Soto, R. A.; Yañez-Fernandez, J. \& Alvarez-Ramirez, J. (2020). OSA-maltodextrin as wall material for encapsulation of essential avocado oil by spray drying. J. Dispers. Sci. Technol., 41, 235-242. https://doi.org/10.1080/01932691.2018.1562939.

Souza, V. G. L.; Rodrigues, C.; Ferreira, L.; Pires, J. R. A.; Duarte, M. P.; Coelhoso, I. \& Fernando, A. L. (2019). In vitro bioactivity of novel chitosan bionanocomposites incorporated with different essential oils. Ind. Crops Prod., 140, 111563. https://doi.org/10.1016/j.indcrop.2019.111563.

Stejskal, V.; Hubert, J.; Aulicky, R. \& Kucerova, Z. (2015). Overview of present and past and pest-associated risks in stored food and feed products: European perspective. J Stored Prod Res, 64, 122-132. https://doi.org/10.1016/j.jspr.2014.12.006.

Suleiman, R.; Williams, D.; Nissen, A.; Bern, C. J. \& Rosentrater, K. A. (2015). Is flint corn naturally resistant to Sitophilus zeamais infestation? J. Stored Prod. Res., 60, 19-24. https://doi.org/10.1016/j.jspr.2014.10.007. 
Sun, Q.; Shang, B.; Wang, L.; Lu, Z. \& Liu, Y. (2016). Cinnamaldehyde inhibits fungal growth and aflatoxin B1 biosynthesis by modulating the oxidative stress response of Aspergillus flavus. Appl. Microbiol. Biotechnol., 100, 1355-1364. https://doi.org/10.1007/s00253-015-7159-z.

Sun, X. D.; Su, P. \& Shan, H. (2017). Mycotoxin Contamination of Maize in China. Compr. Rev. Food Sci., 16, 835-849. https://doi.org/10.1111/15414337.12286.

Suthisut, D.; Fields, P. G. \& Chandrapatya, A. 2011). Contact Toxicity, Feeding Reduction, and Repellency of Essential Oils from Three Plants from the Ginger Family (Zingiberaceae) and their Major Components Against Sitophilus zeamais and Tribolium castaneum. J. Econ. Entomol., 104, 1445-1454. https://doi.org/10.1603/EC11050.

Tajkarimi, M. M.; Ibrahim, S. A. \& Cliver, D. O. (2010). Antimicrobial herb and spice compounds in food. Food Control, 21, 1199-1218. https://doi.org/10.1603/EC11050.

Ti, E. S.; Ta, E. D. \& Am, A. E. A. (2019). Investigation of fungus associated within cooccurrence of aflatoxins and ochratoxin a in cereals from Egypt. Mojt., 5, 92-99. https://doi.org/10.15406/mojt.2019.05.00161.

Torre, J. E.; Gassara, F.; Kouassi, A. P.; Brar, S. K. \& Belkacemi, K. (2015). Spice use in food: Properties and benefits. Crit. Rev. Food. Sci. Nutr., 57, 10781088. https://doi.org/10.1080/10408398.2013.858235.

Torres, C.; Silva, G.; Tapia, M.; Rodríguez, J. C.; Figueroa, I.; Lagunes, A.; Santillán, C.; Robles, A.; Aguilar, S. \& Tucuch, I. (2014). Insecticidal activity of Laurelia sempervirens (Ruiz \&amp; Pav.) Tul. Essential oil against Sitophilus zeamais Motschulsky. Chil. J. Agric. Res., 74, 421-426. http://dx.doi.org/10.4067/S0718-58392014000400007.

Tournas, V. H. \&; Niazi, N. S. (2017). Potentially toxigenic fungi from selected grains and grain products. J. Food Saf., 38. https://doi.org/10.1111/jfs.12422.

Trevizan, L. R. P. \& Baptista, G. C. de. (2000). Resíduos de deltametrina em grãos de trigo e em seus produtos processados, determinados por cromatografia gasosa. Sci. Agric., 57, 199-203. https://doi.org/10.1590/S0103-90162000000200002.

Tripathi, A. K.; Upadhyay, S.; Bhuiyan, M. \& Bhattacharya, P. R. (2009). A review on prospects of essential oils as biopesticide in insect-pest management. J. Pharmacognosy Phytother., 1, 052-063. https://doi.org/10.5897/JPP.9000003.

Ugalde, M. L.; Cezaro, A.; Vedovatto, F.; Paroul, N.; Steffens, J.; Valduga, E.; Backes, G. T.; Franceschi, E. \& Cansian, R. L. (2017). Active starch biopolymeric packaging film for sausages embedded with essential oil of Syzygium aromaticum. J. Food Sci. Technol. Mysore, 54, 2171-2175. https://doi.org/10.1007/s13197017-2624-6

Utchariyakiat, I.; Surassmo, S.; Jaturanpinyo, M.; Khuntayaporn, P. \& Chomnawang, M. T. (2016). Efficacy of cinnamon bark oil and cinnamaldehyde on antimultidrug resistant Pseudomonas aeruginosa and the synergistic effects in combination with other antimicrobial agents. BMC Complement Altern. Med., 16, 158. https://doi.org/10.1186/s12906-016-1134-9.

Vedovatto, F.; Junior, C.V.; Astolfi, V.; Mielniczki-Pereira, A. A.; Roman, S. S.; Paroul, N.; Cansian, R. L. (2015). Essential oil of Cinnamodendron dinisii Schwanke for the control of Sitophilus zeamais Motschulsky (Coleoptera: Curculionidae). Rev Bras Pl Med., 17, 1055-1060, 2015.

Vélez, M.; Barbosa, W. F.; Quintero, J.; Chediak, M. \& Guedes, R. N. C. (2017). Deltamethrin- and spinosad-mediated survival, activity and avoidance of the grain weevils Sitophilus granarius and S. zeamais. J. Stored Prod. Res., 74, 56-65. https://doi.org/10.1016/j.jspr.2017.10.002.

Vélez, M.; Bernardes, R. C.; Barbosa, W. F.; Santos, J. C. \& Guedes, R. N. C. (2019). Walking activity and dispersal on deltamethrin- and spinosad-treated grains by the maize weevil Sitophilus zeamais. Crop Protection, 118, 50-56. https://doi.org/10.1016/j.cropro.2018.12.013.

Villaverde, J. J.; Sevilla-Morán, B.; Sandín-España, P.; López-Goti, C. \& Alonso-Prados, J. L. (2014). Biopesticides in the framework of the European Pesticide Regulation (EC) No. 1107/2009. Pest Manag. Sci., 70, 2-5. https://doi.org/10.1002/ps.3663.

Voris, D. G. R.; Afonso, C. H. V.; Filho, C. A. C.; Almeida, F.; Conceição, O. J.; Brito, D. Q. M.; Moraes, C. S.; Lima, K. S. C.; Lima, J. B. P.; Mirand, M. G.; Lima, A. L. S.; Avelar, K. E. S.; Friede, R. \& Lima, A. L. S. (2017). Estudos Etnofarmacológicos de óleos essenciais com atividade larvicida contra o Mosquito Aedes Aegypti. Semioses (Rio de Janeiro), 11, 86-94.

Wandrey, C.; Bartkowiak, A. \& Harding, S. E. (2010). Materials for Encapsulation. In: Encapsulation Technologies for Active Food Ingredients and Food Processing. New York, NY: Springer New York, p. 31-100. https://doi.org/10.1007/978-1-4419-1008-0_3.

Wang, Y.; Zhang, L.-T.; Feng, Y.-X.; Zhang, D.; Guo, S.-S.; Pang, X.; Geng, Z.-F.; Xi, C. \& Du, S.-S. (2019). Comparative evaluation of the chemical composition and bioactivities of essential oils from four spice plants (Lauraceae) against stored-product insects. Ind. Crops Prod., 140 , 111640. https://doi.org/10.1016/j.indcrop.2019.111640.

Wu, F. (2015). Global impacts of aflatoxin in maize: trade and human health. World Mycotoxin J., 8, 137-142. https://doi.org/10.3920/WMJ2014.1737.

Xie, Y.; Huang, Q.; Wang, Z.; Cao, H. \& Zhang, D. (2017). Structure-activity relationships of cinnamaldehyde and eugenol derivatives against plant pathogenic fungi. Ind. Crops Prod., 97, 388-394. https://doi.org/10.1016/j.indcrop.2016.12.043.

Yang, J.; Xiao, J. \& Ding, L. (2009). An investigation into the application of konjac glucomannan as a flavor encapsulant. Eur. Food Res. Technol., 229, 467474. https://doi.org/10.1007/s00217-009-1084-2.

Yoon, M.-Y.; Cha, B. \& Kim, J.-C. (2013). Recent Trends in Studies on Botanical Fungicides in Agriculture. Plant Pathol. J, 29, 1-9. https://doi.org/10.5423/PPJ.RW.05.2012.0072. 